\title{
The Gloss to the Saunteen Kesta (Seventeen Statutes) of the Frisian Land Law
}

\author{
Jan Hallebeek \\ Professor of European Legal History, Faculty of Law, Vrije Universiteit \\ Amsterdam \\ j.hallebeek@vu.nl
}

\section{Summary}

The Seventeen Statutes is one of the oldest classical texts of Old Frisian Law. In its late fifteenth century edition, as part of the Frisian Land Law, it was provided with Latin glosses. Analysis of these glosses, which were scarcely investigated until now, enables us to pronounce with more certainty upon the date of both the Frisian Land Law, as a compilation, and its Gloss. Moreover, the glosses to the Seventeen Statutes reflect a considerable increase of ecclesiastical competence, point to certain principles of Romanocanonical procedure and use Roman law texts when applying provisions of indigenous law. This all may indicate a stronger presence of learned law in late medieval Friesland than previously assumed.

\section{Keywords}

Friesland - Seventeen Statutes (Zeventien Keuren, Saunteen Kesta) - reception of Canon law and Roman law

The Frisian Land Law (Freeska Landriucht) is a compilation of indigenous, West Frisian (westerlauwers) law texts of the closely connected lands of Oos-

* This contribution is an elaborated version of a paper presented on 23 April 2018 in Leeuwarden at the occasion of the 'First Conference on Frisian Humanities'. The author would like to thank Dieneke Hempenius-van Dijk, Han Nijdam, Oebele Vries and Boudewijn Sirks for their commentary on the draft version of this paper. The author would like to thank Frances Gilligan for correcting the English. 
tergo and Westergo. These territories, once Frankish shires, are nowadays part of the Dutch Province of Friesland. Fourteen of these law texts are considered to belong to a kind of classical canon, six are additional texts's. When exactly this compilation came into being, is difficult to say. The printed edition first came to light at the end of the fifteenth century (c. 1485), but it is under dispute whether this edition was preceded by a manuscript tradition, or whether the texts were compiled not long before they were printed or even in view of the printed edition. Nevertheless, the incunable of the Frisian Land Law, known as 'Druk' or D, also contains an extensive Latin Gloss 2 . Relevant literature tells us next to nothing about the origin, genesis or nature of this Gloss. It is probable that the glosses go, at least partially, back to an earlier manuscript tradition, since some of these can be traced back in other late medieval law texts, which may point at a common origin in the past ${ }^{3}$. However, if the glosses stem from an earlier tradition, so would the Frisian Land Law itself.

1 See O. Vries, Thet is ac londriucht. Landrechte und Landrecht im mittelalterlichen Friesland, in: Directions for Old Frisian Philology [Amsterdamer Beiträge zur älteren Germanistik, 73], ed. R.H. Bremmer, S. Laker and O. Vries, Amsterdam/New York 2014, p. 571-587, at p. 582.

2 Dat aelde freeska landriucht [s.l.][c. 1486-1487]. It was reprinted various times. C. Schotanus, Beschryvinge van de heerlyckheydt van Frieslandt tusschen 't Flie end de Lauwers, [s.l.] 1655, p. 36-106 (with glosses); [P. Wierdsma \& P. Brantsma], Oude Friesche wetten met eene Nederduitsche vertaling, Eerste stuk, Campen/Leeuwarden 1782 (without glosses, with Dutch translation); K. von Richthofen, Friesische Rechtsquellen, Berlijn 1840, p. 384-441. A contemporary edition, provided with an English translation, is forthcoming. In this contribution all glosses to the Seventeen Statutes are produced in the main text, albeit without a critical apparatus. These glosses were edited together with Hylkje de Jong.

3 The first text of the Frisian Land Law, Haet is riucht? (What is Law?) and part of another text, the Older Skeltanariucht (Older Magistrate Law), are in the manuscript Codex Roorda (Leeuwarden, Tresoar, ms. Richthofen 6), dating from about 1500, provided with similar, but not identical glosses. The manuscript Jus Municipale Frisionum, a copy from about 1538 of several fifteenth century manuscripts (Leeuwarden, Tresoar, ms. Richthofen 5 ), contains the two single glosses to Bireknade Bota (Tariff of Compositions), viz. the gloss supradicta emenda fiunt and the gloss intellige de puero doli capace. They can be found in the edition of this manuscript; see Westerlauwerssches Recht I. Jus Municipale Frisonum [Altfriesische Rechtsquellen, 6], ed. W.J. Buma / W. Ebel, Vol. I-II, Göttingen 1977, J XXVIII, 272 (Vol. II, p. 526) and J XXVIII, 277 (Vol. II, p. 528). See about these glosses: H. Nijdam, Lichaam, eer en recht in middeleeuws Friesland. Een studie naar oudfriese boeteregisters, Hilversum 2008, p. 99. The manuscript Codex Aysma (Oxford, Bodleian Library, ms. Junius 78), another collection of Frisian legal texts from around 1500 , contains comparable Latin parts and glosses, referring to sources and writings of learned law. The Codex Aysma was edited and translated into German. See Codex Aysma; die altfriesischen Texte, ed. W.J. Buma, P. Gerbenzon and M. Tragter-Schubert, Assen/Maastricht 1993 . 
Unlike the Frisian main text (the Land Law), its Gloss, which consists of 190 single glosses, had been largely neglected ${ }^{4}$. In this contribution I would like to break the silence by focussing on the 29 glosses added to the so-called Seventeen Statutes or Saunteen Kesta, which is considered to be one of the oldest parts of the Frisian Land Law. It contains the main fundamental privileges of the Frisians. According to the saga of Magnus, it was granted by Charlemagne $(\dagger 814)$ by way of thanks for the liberation of the city of Rome, but it was probably customary law, compiled in the course of the 13th century, starting from 1248 , although some of its provisions may go back to earlier times, some even indeed to the era of Charlemagne 5 . The word 'statute' is used here not in the sense of a provision, imposed by public authorities. It is the translation of keur (Dutch) or kest (Old Frisian), i.e. a provision of chosen (gekoren) law.

The text of the Seventeen Statutes is also handed down independently in a number of manuscripts, some being older, but only in the printed edition of the Frisian Land Law and in the Codex Unia (see below) was it provided with glosses. An analysis of these glosses and the sources it refers to can cast light on the Frisian law of the late Middle Ages. It can show how the Statutes were interpreted, at least by the learned jurist(s) who composed the Gloss. It may also reveal to what extent learned law, Roman and Canon, was already present in late medieval Friesland ${ }^{6}$.

Not all of the Seventeen Statutes are provided with glosses and, as will appear below, the glosses are not of an identical nature. I will first describe the content of the glosses and the sources they refer to; see what they reveal about their

4 Gerbenzon dealt extensively with Haet is riucht?, but did not pronounce upon the glosses. See P. Gerbenzon, Bijdrage tot het bronnenonderzoek van Haet is riocht, Us Wurk 20 (1971), p. 1-18.

5 J.R.G. Schuur, Het ontstaan van de Zeventien Keuren en Vierentwintig Landrechten, It Baeken 72 (2010), p. 175-214. According to Algra the Seventeen Statutes came into being around 1225 . See N.E. Algra, Zeventien keuren en vierentwintig landrechten, Doorn $1991^{2}$, p. 278 . For earlier hypotheses about the dating of the Seventeen Statutes see J. Hoekstra, Die gemeinfriesischen Siebzehn Küren, Assen 1941, p. 13-26.

6 What Gerbenzon stated about a thorough analysis of the sources of the Gloss to the Jurisprudentia Frisica also holds good for the Gloss to the Seventeen Statutes, viz. that it can provide insight into the libraries of the Frisian jurists who worked on the various law texts and their glosses. See P. Gerbenzon, Aantekeningen over de Jurisprudentia Frisica. Een laatvijftiende-eeuwse Westerlauwers-Friese bewerking van de Excerpta legum, TR 57 (1989), p. 21-67, p. 339-374, at p. 23-24. 
nature and genesis; and what can be derived from their specific relation to the Frisian main text.

First, it has to be noted, that the lemmata of the glosses cannot always be identically traced in the main text. This main text is written in the version of Old Frisian as spoken in the fifteenth century, whereas the lemmata of the glosses belong to an earlier kind of Old Frisian. The former text version of the Seventeen Statutes is indeed preserved, viz. in the Jus Municipale Frisonum (J) and the Codex Unia $(\mathrm{U})^{7}$. It is possible that the editor(s) of the Frisian Land Law adapted the text of the Seventeen Statutes linguistically to the common parlance of their own days, but did not adapt the lemmata of the glosses. They attempted to render the text of the Seventeen Statutes more accessible for the late fifteenth century by adapting the spelling and by replacing conceptions of which the meaning was no longer clear with more contemporary words. However, most of the time it is clear to which specific words and phrases of the main text the glosses refer. Below these words are reproduced between brackets. The fact that the glosses refer to an older version of the main text, may indicate that they came into being some time before the end of the fifteenth century.

\subsection{The glosses to the First Statute (p. 53)}

The First Statute grants each Frisian the unhampered possession of his property as long as he has not forfeited that right (also langhe als hyt naet foerwrocht habbe). This short statement is provided with two glosses. The first, without a lemma, confirms the legal principle, just stated, thereby referring to texts of Roman and Canon law, and interprets the words 'as long as he has not forfeited that right' as 'unless legitimately sentenced by the court'. The Roman law texts, referred to, maintain that it would not be equitable that free born persons lack the authority to alienate their things (D. 37,12,2), that every man has the free judgement to do as he decides (C. 8,53,35,5), that everyone concludes not all, but most of his transactions at his own discretion (C. 4,35,21) and that everyone is free to enter or not to enter into a contract $($ C. 4,10,5). The texts of Canon law deal with the freedom everyone has to determine his Last Will (C.13 q.2 c.7) and the exception to this principle, viz. that if a dying person confers his assets to a monastery, the parish Church is entitled to a portio canonica ( $\mathrm{x} 3,28,4)$.

7 Buma / Ebel, Westerlauwerssches Recht (supra, n. 3), Vol. I, p. 135-146. See for the Seventeen Statutes in the Codex Unia: Bodleian Library Oxford, ms. Junius 49 (Apographa), fol. 31v-32v and ms Junius 109 (Collationes), p. 49 ff. The latter manuscript also contains glosses, probably copied from 'Druk'. 
Nullus rebus suis sit spoliandus nisi legitime coram iudice conuictus. Fas est unicuique disponere de rebus suis qualitercunque sibi placet, ff. si a paren. quis man. fue. l. ii. (D. 37,12,2), C. de dona. Si quis argen. (C. $8,53,35,5)$, C. manda. In re mandata (C. 4,35,21), C. de actio. et obliga. 1 . Sicut (C. 4,10,5). Quilibet est arbiter et moderator in re propria, ff. si quis a parente manu. fuerit l. ii. (D. 37,12,2), xiii. q. ii. c. Placuit (C.13 q.2 c.7), sed aliud de sepult. c. De his in fi. (x 3,28,4).

The second gloss, the gloss also langh (also langhe), refers to texts of Roman law, dealing with people who have lost their assets, such as those exiled or convicted of crime (the entire titles D. 48,20 and C. 9,49), Manicheans and Donatists, whose goods were confiscated (C. 1,5,4), and children, disinherited because of their ingratitude (Nov. 22,46,4 = Auth. Coll. 4,1,46,4).

Also langh De hoc ff. et. C. de bonis damp. per totum (D. 48,20 and C. $9,49)$, C. de here. 1. Manichaeos (C. 1,5,4), in auth. de nupt. § Ingratitudinem (Nov. 22,46,4 = Auth. Coll. 4,1,46,4).

\subsection{The glosses to the Second Statute (p. 54)}

The Second Statute grants protection to sacred places (godeshusem) and clerics (godesliodem). Whoever breaches the peace of a Church, will have to pay a fine of 72 pounds to the Church and three pounds to the frana, i.e. the representative of the lord of the land ${ }^{8}$. The Second Statute also lays down what kind of currency unit is meant here. It explains why the penalty of 72 pounds was altered into a penalty of 72 shillings.

Two glosses are added. The first gloss, the gloss alle godes husem, contains primarily additional provisions of Canon law. It uses the rule, that the Church should be a sanctuary, secure from violent feuds, as a steppingstone to discuss ecclesiastical immunity and asylum. First it explains that immunity of Church buildings is a right, derived (extractum) from the Codex-title on persons who seek asylum in a Church (C. 1,12) and from Canon law. The Canon law texts state that free persons, who have committed a crime and taken refuge in a Church, may not be expelled by force (the decretal Inter alia of Innocent III $[\dagger$ 1216], $\mathrm{x} 3,49,6)$, that lay individuals, who arrogate rights of the Church, can be kept in line by means of ecclesiastical censure $\left(x_{2,2,16)}\right.$ and that those who seek refuge may not be dragged out of the forecourt of a Church or the house of a bishop (C.17 q.4 c.36).

8 Algra, Zeventien keuren (supra, n. 5), p. 220-222, 231-232. 
alle godes husem Hoc ius uidetur extractum C. de his qui fugiunt ad ecclesiam per totum (C. 1,12), extra de emuni. eccl. Inter alia (x 3,49,6), de for. conpet. Conquestus (x 2,2,16), xviii q. iiii <Id > constituimus (C.17 q.4 c.36).

The second gloss, the gloss alle godes mannen (alle godesliodem), gives more additional rules, mainly derived from Canon law. It displays exceptions to the general principle of Church asylum. It states that notorious robbers and plunderers of the fields are excluded from asylum. They can rightly be dragged out. The gloss bases this exception on a provision of Roman law, stating that those caught in committing a crime may be castigated (Nov. 17,4,2 [in fine] = Auth. Coll. 3,4,2) and on the decretal Inter alia (x 3,49,6), just referred to, which literally mentions the two exceptional cases ${ }^{9}$.

The second gloss continues with three remarks. The first explains that the one who infringes on ecclesiastical immunity is punished in two ways. He is excommunicated through the act of taking something from the Church by robbing and stealing (thus sententia lata?). The gloss refers here to C.17 q.4 C.19 ${ }^{10}$. Moreover, the wrongdoer has to provide satisfaction to the one injured. This is read in X 5,39,9, a decretal discussing a comparable, but not identical case. In legal doctrine the latter (satisfaction) is usually not termed as punishment, because of its mere reipersecutory and not penal nature.

Secondly, the gloss maintains that goods of Churches or religious places and persons, staying in these places, enjoy the same privilege, which the gloss substantiates by referring to various authoritative texts, such as a provision in another part of the Frisian Land Law, viz. the Synodical Law (Syndriucht), determining the fines for those who violate the immunity of Churches and commit sacrilege ${ }^{11}$. Moreover, according to Gratian's Decree, servants of the Church have an exempt status and should not be burdened with public or private duties (C.12 q.2 c.69) and those who rob things from Churches and bishops are excommunicated (C.16 q.1 c.58). According to the gloss obligata to X 3,21,5, the goods of a bishop enjoy the same privilege as the goods of the Church.

$9 \quad$ The gloss alle godes mannen speaks about publici latrones et populatores agrorum, the decretal Inter alia ad x 3,49,6 speaks about publicus latro and nocturnus depopulator agrorum.

10 However, the connection between on the one hand sacrilege and 'taking away' and on the other the two punishments, is not mentioned in C.17 q.4 C.19, but in C.17 q.4 c.20.

11 The Synodical law (Syndriucht) is the eleventh text of the Frisian Land Law. 
Moreover, the Liber Sextus of 1298 rules that whoever compels the Church to pay toll or to pay for safe conduct is excommunicated (VI 3,20,4) ${ }^{12}$.

In the third place, the gloss notes that currency units, mentioned in legal provisions, should be taken as the normal currency as in circulation. This is supported by Roman law and Canon law. The former rules that no one is compelled to sell something, if he does not like the price, especially if parties act in conformity with the regional customs (D. 18,1,71). The latter speaks about 'five coins of the usual money' (quinque solidorum usualis monetae, $\mathrm{x} 5,26,2$ ) and maintains that if nothing is said about the currency, the coins mentioned should be understood as the usual money (gloss usualis to $\mathrm{x} 5,36,7$ ). This is further explained by referring to the beginning of the first part of the Frisian Land Law, viz. What is Law? (Haet is riucht?), where a text from Gratian's Decree was brought up, stating that every legal precept has to be in accordance with the place, the time and the territory (D.4 c.2). The gloss to some extent justifies the change of a penalty of 72 pounds into one of 72 shillings. It is disputed, though, in the secondary literature, whether this change was a mere conversion or also implied a mitigation or reduction ${ }^{13}$. The gloss just endorses an adaptation to passable currency.

alle godes mannen exceptis publicis latronibus et populatoribus agrorum quos non defendit ecclesia, sed licite extrahuntur in auc. de manda. prin. Quod si delinquentes coll. iii. (Nov. 17,4,2 = Auth. Coll. 3,4,2), extra de emuni. ecclesiarum c. Inter alia (x 3,49,6). Nota. Qui uiolat emunitatem ecclesiasticam duplici ratione punitur. Primo est excomunicatus illo facto, si bona rapiendo uel furando subtrahit ecclesie, xvii. q. iii. c. Nullus (C.17 q.4 c.19). Secunda pena relinquitur arbitrio iudicis et dabitur persone uel loco ubi delinquit uel cui immunitas est lesa, extra de sen. excommuni. c. Parochianis (x 5,39,9). Nota. Bona ecclesiarum et locorum religiosorum et persone earum eadem gaudent priuilegio; concordat infra penultimum ius sinodale et xvi. q. i. Similiter (C.16 q.1 c.58), extra de pigno. c. Ex litteris in glossa penultima, et de censi. Quamquam in vi (vI 3,20,4) et xii q.ii c. Ecclesiarum (C.12 q.2 c.69), et de priuilegiis c. Licet li. vi (VI $5,7,11)$. Nota. Vbicumque certa quantitas pecunie ponitur in lege ut est solidorum denariorum, semper intelligendum est de moneta usuali currente per terram, ff. de contrahen. empti. l. Imperatores (D. 18,1,71),

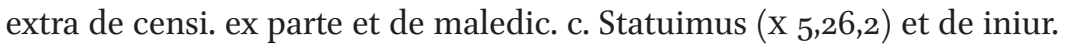

There is also a reference to VI $5,7,11$ but this allegation may be corrupt, since its significance for the purport of the gloss is far from clear.

See Hoekstra, Die gemeinfriesischen (supra, n. 5), p. 147 with references to older literature. 
et c. Olim super uerbo usualis (the gloss usualis ad x 5.36.7), quia lex debet esse loco et tempori et patrie conueniens, iiii. d. c. Erit (D.4 c.2), ut patet eciam supra 'Quid sit lex?' in principio.

\subsection{The glosses to the Third Statute (p. 55)}

The fundamental right, guaranteed by the Third Statute, is the right to live on one's own property, free from any assault. One can only be deprived from such a right as a consequence of a doem of the asega and on the basis of the Land Law. The latter term is used here in the sense of all the indigenous provisions of the Frisians, either orally handed down or put in writing. The asega, mentioned here, was an official of the court of the land, who could pronounce a doem, i.e. a coercive instruction how to sentence in a specific case ${ }^{14}$. The role of the asega must have come to an end around 1250, so probably before the glosses were written. This first part of the Third Statute is provided with three glosses.

The first gloss, having no lemma, explains that this protection is also written law: it is ius scriptum. The latter term is probably meant here in the sense of Roman law in view of the references, now following, to texts in the Corpus iuris. The purport of these texts is that possession is firstly protected by possessory remedies (the interdicta 'uti possidetis' and 'utrubi'), which grant the actual possessor the procedural benefit of acting as defendant in case of petitory litigation. This procedural benefit is further explained by the five allegations which follow; all having the same purport, viz. that the burden of proof (of being entitled) lies with the plaintiff who vindicates his property by bringing a claim against the possessor.

Item quod nemini facienda est iniuria in re propria uel possessione sua. Hoc ius scriptum est, Insti. de interdic. § Retinende (Inst. 4,15,4) cum § Commode $<\mathrm{m}>$ aut possedendi (Inst. 4,15,4 in fine), C. de eden. l. Qui accusare (C. 2,1,4), C. de rei uindicati. l. fi. (C. 3,32,28), ff. si usuf. petatur l. Vtifrui (D. 7,6,5 in pr.), C. de peti. heredita. l. Cogi (C. 3,31,11), C. de probati. l. ii $($ C. $4,19,2)$.

The second gloss, the gloss onbirawed (onbirawet), deals with another right which the possessor has according to learned law. Apart from bringing a possessory remedy, he can rightfully defend his possession in a physical way. When being expelled from it, he may, as an immediate response, take up arms. This

14 Algra, Zeventien keuren (supra, n. 5), p. 216-220. Algra rejected the opinion of Köbler that the asega merely provided information about the law to be applied. Ibid., p. 255-264. 
right is substantiated by the decretal $\operatorname{Olim}(\mathrm{x} 2,13,12)$ of Innocent III, by Roman law texts and by the commentary of Innocent IV $(\dagger 1254)$ on the same decretal Olim. The decretal Olim explains that an intruder can be expelled immediately by force. The Roman law texts are not always convincing. The first states that the stipulator's question should be immediately followed by the promisor's response (D. 45,1,137pr). Apparently this implies, analogously, that taking up arms should be an immediate reaction in order to be legitimate. The second allegation (C. 8,4,1) allows the defence of possession against violence. The third one (D. 43,16,1,15) seems to be corrupt. Another paragraph in the same lex, stating that averting violence by using violence is permissible (D. 43,16,1,27), would have been more obvious to support the statement of the gloss. In his commentary to the decretal Olim, Innocent IV states that a cleric does not render himself irregularis, when he fights against his attackers or defends himself in a different way ${ }^{15}$. As a final remark the second gloss says that a similar right can be found in the first provision of the Land Law. This time the term Land Law (Landriucht) indicates another classical law text belonging to the Frisian Land Law texts, viz. the Twenty-four Land Laws (xxiiii landriuchta) ${ }^{16}$. The first of these indeed guarantees unhampered possession of an individual's own property.

Onbirawed Extra de resti. spo. c. Olim (x 2,13,12). Vnde cuilibet licitum est mouere bellum pro defensione sui et rerum suarum, nec hoc proprie dicitur bellum, sed defensio. Eciam si eiciatur de possessione sua, licet ei in continenti pugnare, ut ibi et ff. de u. obli. l. Continuus (D. 45,1,137pr), c. unde ui l. i (C. 8,4,1), ff. de ui et ui ar. l. i. § Quod igitur (D. 43,16,1,15), et Innocentius, de resti. spolia. c. Olim (X 2,13,12). Simile ius inueniri potest in primo iure ciuili quod dicitur landriucht.

The third gloss, the gloss datmet him mit tele (dat met hem ofwinne mit tale), refers to a provision in the Codex Justinianus, stating that property of land has to be claimed in court (C. 4,19,2), which may indicate that the use of force is restricted to the possessor's immediate defence against infringement.

Datmet him mit tele C. de probati. l. Possessiones (C. 4,19,2).

15 Commentaria ad x 2,13,12, n. 9. See Innocentius IV, Commentaria super libros quinque decretalium, Frankfurt 1570, fol. 232 ra. Irrigularis is a technical term, indicating that a cleric is no longer qualified for receiving prebendaryships or major orders. 
As just seen, the Third Statute refers to the role of the asega in litigation. The Frisian main text of the Seventeen Statutes now continues with a concise exposition of the requirements for becoming asega. The latter has to be sworn into office before the Emperor in Rome and be elected by the people. The contents of the oath are described explicitly, viz. to treat all people, including widows and orphans, as if they are relatives in the third degree. Moreover, it is stated that the asega may not accept bribes. Otherwise he loses his competence to pronounce his doem, because asega's, just like priests, are 'the eyes of Christianity'. The meaning of this part of the main text is somewhat obscure. Who is meant by the Emperor in Rome (dyn keyser to Roem). The Western Roman Empire had collapsed many centuries before. Could it have been the Emperor of the Holy Roman Empire? I will return to this question below ${ }^{17}$.

The passage on the requirements for functioning as asega, is provided with three glosses. The first gloss, the gloss Ende deer aegh nen aesga (di aesga aegh nen doem), can also be found in a more extensive version in the Gloss to Jurisprudentia Frisica 59:5, a compilation belonging to a younger type of legal literature than the Frisian Land Law ${ }^{18}$. The gloss says that the provision concerning the oath is derived or adopted (hoc sumptum est) from the Codex Justinianus (C. 3,1,14). This implies that the jurist(s) who composed the Gloss to the Seventeen Statutes seem to consider the 'keyser to Roem' to be the Roman Emperor of Antiquity, which is far from obvious ${ }^{19}$. Secondly, the asega is put on a par here with the iudex or judge of Roman law, despite the fact that their functions in litigation may have been quite different. The asega was a representative of the people, who in his doem gave a coercive instruction about the application of customary law in the case under dispute. If the members of the ting (ommestand) consented, the judgement became final and could be executed through the command (ban) of the plaintiff ${ }^{20}$. The Roman iudex, by contrast, was a magistrate who pronounced verdict in the name of the Emperor. Is this just an analogy or were the author(s) of the glosses no longer aware of the role the asega once had? I will return to this question below.

Ende deer aegh nen aesga Hoc sumptum est C. de iudi. l. Rem non nouam (C. 3,1,14 in pr.).

\footnotetext{
17 For the older opinions concerning the meaning of this fragment see Hoekstra, Die gemeinfriesischen (supra, n. 5), p. 150-152.

18 Codex Roorda (supra, n. 3), p. 233: "hoc jus sumptum est (...)".

19 On the gloss to Jurisprudentia Frisica 59:5 see Gerbenzon, Aantekeningen (supra, n. 6), p. 345 .

20 Algra, Zeventien keuren (supra, n. 5), p. 294.
} 
The second gloss, the gloss doer dis edis wille (om dat hi swer), explains that the prohibition in the Statute to accept bribes is presumed to apply to judges in view of their oath. This is based on a text from Gratian's Decree (C.1 q.7 c.26), adopted from the Codex Justinianus (C. 9,27,6) ${ }^{21}$.

Doer dis edis wille Nota quod presumitur pro iudice ratione iuramenti i. q. vii. c. Sancimus (C.1 q.7 c.26), de presump. c. Ad audienciam circa medium (x 2,26,13 i.m.).

The third gloss, the gloss ende als di aesga nympt onriucht (ende als di aesga aec nympt onriuchte), rules that sentences, resulting from bribery, are null and void, as stated in C. 7,64,7. The judge can be prosecuted under the lex Iulia repetundarum (C. 9,27,4), has to make restitution in quadruple (C. 9,27,1) and also makes the case 'his own' (litem suam facere, see D. 5,1,15). The one who bribes the judge, loses his case (C. 7,49,1). The gloss continues by stating that according to the 'new law', i.e. the Authenticum, this person forfeits the fourfold. The latter statement, however, is not a faithful representation of the authentica Nouo iure qui dicit, inserted after C. 7,49,1, which is derived from the Authenticum (Nov. 124,2 = Auth. Coll. 9,5,2).

Ende als di aesga nympt onriucht Sentencia uenalis ipso facto est nulla, C. quando prouoca. ne. Venales (C. 7,64,7). Et iudex accusari potest pena legis Iulie repetunda., C. ad leg. iu. repet. l. Iubemus (C. 9,27,4) et munera percepta in quadruplum restituat, C. e.ti.l.i (C. 9,27,1) et litem facit suam, ff. de iudi. l. Si filius fa. (D. 5,1,15 in pr.) et qui corrumpit causam amittit, C. de pen. iudi. l. i. et ii. (C. 7,49,1-2), sed nouo iure quadruplum.

\subsection{The glosses to the Sixth Statute (p. $\left.5^{6}\right)$}

The Sixth Statute is aimed at the protection of immoveable property belonging to the Church. It lays down in which way the entitlement of the Church can be established. Seven compurgators are required for vindicating plots of land for the Church and they all should meet a number of criteria.

The text of the Statute is provided with three glosses. The first one, the gloss jefta caped, simply refers to the general prohibition to alienate ecclesiastical property, as enshrined in the Codex Justinianus (C. 1,2,14).

Jefta caped De hoc in l. Iubemus C. de sac. sanc. eccl. (C. 1,2,14). 
The second gloss, the gloss uessa menedich, indicates regarding the exclusion of perjurers as compurgator to the Liber Extra, where it is stated that criminals cannot testify $(\mathrm{X} 2,20,54)$. This statement leads associatively to the four things which can pervert human judgement, i.e. love, fear, hate and gifts. This phrase goes back to a text in Gratian's Decree (C.11 q.3 c.78) and a variant can be found in a decretal from the Liber Sextus (vi 2,14,1). The latter mentions 'hate, partiality, fear, reward or prospect of reward'. The phrase in Gratian's Decree in its turn probably goes back to a fragment in the Sentences of Isidore of Seville $(\dagger 636)^{22}$.

Uessa menedich Extra de testi. c. Testimonium (x 2,20,54), quia enormibus criminibus heretici testificari non possunt. Nota. Quatuor modis corrupitur iudicium, scilicet amore, timore, odio et munere, xi. q. iii Quatuor (C.11 q.3 c.78), de sen. et re iudi. Cum eterni li. vi (vi 2,14,1).

The third gloss, the gloss karina schieldich, is of a mere explanatory nature. The Frisian main text requires that compurgators should be disqualified by sins, obliging them to perform a karina, while the gloss in further explanation of this term refers to the Liber Extra (x 4,4,2). Carina is a penance, consisting in living forty days on bread and water.

Karina schieldich De karena uide extra de sponsa duorum c. Accepisti $(\mathrm{x} 4,4,2)$.

\subsection{The glosses to the Eighth Statute (p.57)}

The Eighth Statute determines the legal position of the huisman, more specifically in relation to his lord and King. The term huisman is difficult to translate. It is any man with a household of his own, i.e. a dwelling place and yard, thus every common farmer ${ }^{23}$. On the one hand, the Statute fundamentally restricts the huisman's right to bring proceedings against his landlord, but on the other hand it grants him protection against his lord. It guarantees him certain procedural rights, when sued. If he denies an allegation, brought against him, for example, he may have his defence confirmed by twelve compurgators. Moreover, he cannot be compelled to fight a duel against his lord.

The Frisian text of this Statute is provided with two glosses. The first one, the gloss huisman (husman), indicates what kind of rights should not be fully enforced against the King, viz. the right of emphytheusis, dealt with in Codex-

22 Cf. Isidorus Hispalensis, Liber Tertius Sententiarum, Cap. LIV, n. 7.

23 Algra, Zeventien keuren (supra, n. 5), p. 314-315 and note 91. 
title 4,66, and the right of monopoly, dealt with in Codex-title 4,59. As a matter of fact, such rights cannot have existed in an identical form in Frisian indigenous law but the gloss may refer to Frisian equivalents. The Roman emphytheusis was a kind of hereditary tenure. The first gloss mentions two arguments. The first is derived from C. 2,15(16),2, which says that no one may put the imperial standard on the tenement he possesses without judicial authorization. The second is probably derived from a Bible-text. Its purport is that everyone is held to honour his master and not to anger him, so that one will not anger the soul of the mighty. This text seems to be a paraphrase and not a fragment, literally quoted from the Latin Vulgate. In view of the words 'consilio Salomonis' it is probably derived from Proverbs, Ecclesiastes, Canticles or Wisdom.

It may be noted here, that present-day secondary literature sometimes casts a totally different light on the meaning of this first line of the Eighth Statute than the gloss huisman does. The literature interprets this provision as the huisman not being compelled to enter into a duel, or not undertaking subversive activities against the public authorities ${ }^{24}$, whereas the gloss interprets the provision as limiting one's resistance to the King and proceeding with due caution when enforcing one's rights. I will return to this discrepancy below.

Huisman Hoc potest intelligi de iure emphiteotico C. de iure emphi. l. ii. (C. 4,66,2) uel monopoliis C. eodem libro (C. 4,59) ut dicitur C. ut nemo priuatus l. ii. (C. 2,15[16],2). Quilibet tenetur dominum suum reuereri nec ipsum exasperare consilio Salomonis ne exasperaueris animum potentis.

The second gloss, the gloss sikarade mit xii, indicates the reason why the huisman has certain privileges in his relation to the authorities: his rustic simplicity has to be taken into account, as stated in C. $6,23,3^{25}$. The gloss concludes with the remark that this provision may be nullified for many statements of the Land Law. The term 'this provision' (hec lex) probably refers to the text of C. 6,23,31. The author apparently wants to say that in many respects the Frisian Land Law does not take the simplicity of common farmers into consideration.

24 Cf. Algra, Zeventien keuren (supra, n. 5), p. 313-316 and Hoekstra, Die gemeinfriesischen (supra, n. 5), p. 157 with references to the older literature. The interpretation of Algra is followed by Vries in his Dutch translation; see O. Vries, Asega, is het dingtijd? De hoogtepunten van de Oudfriese tekstoverlevering, Leeuwarden/Utrecht 2007, p. 87.

25 The allegation in the incunable is corrupt; all versions have in full (no abbreviation) 'C. de testibus', which is C. 4,20, but this should be 'C. de testamentis', which is C. 6,23. 
Sikarade mit xii. Nam rusticitati et simplicitati parcendum est, C. de testamentis l. ult. (C. 6,23,21). Et potest hec lex anullari ad multa hic posita inda landriucht.

\subsection{The gloss to the Ninth Statute (p. 57)}

The Ninth Statute obliges the Frisians to pay tax for maintaining public order (ferdpenninghen) and a property tax (huuslaga). In return, they will have free and safe passage over public roads and waterways. Only one gloss is added, the gloss ferd penninghen, referring to Gratian's Decree, where it is said that the Church pays taxes only for external affairs (C.23 q.8 c.22 $)^{26}$.

Ferd penninghen Nota. Causa pacifice ambulationis in stratis marinis et terrenis quilibet tenetur soluere regi nummum et non alii, nisi seruauerit pacem, ut xxiii. q. viii Tributum (C.23 q.8 c.22).

\subsection{The glosses to the Eleventh Statute (p. 6o-61)}

The Eleventh Statute grants protection to widows, orphans, those who are defenceless, pilgrims, certain penitents, ecclesiastical messengers and minors against robbery and infringements on their physical integrity. These categories of protected persons, at least some, may stem from an older secular truce (treuga terrae). The Statute is provided with two extensive glosses.

The first gloss, which lacks a lemma, starts by stating that as regards the protection of persons, brought up in the Statute, the Church is competent. This is the so-called competence ratione personarum, which the Church in late medieval times claimed to have in order to protect personae miserabiles. According to the gloss this implies that those mentioned should be defended by a priest $^{27}$ before an ecclesiastical court ${ }^{28}$. The gloss continues with referring to some verses from Psalm 10: 'His eyes look for the poor' (verse 9) and 'You will offer help to the orphan' (verse 14). The first quotation is entirely taken out of context. The verse, also in the context of the Vulgate-text (Psalm 9.30), refers to the sinner who watches out for the poor with malicious intent. Such text

26 Based on Matthew 17.25-27, where Jesus, in view of paying taxes, ordered Saint Peter to catch a fish, which would have a coin in its mouth.

27 Thereby referring to Gratian's Decree: a penitent, should in case of necessary litigation rather look for an ecclesiastical than a secular verdict (C.11 q.1 c.34).

28 Here the Gloss has two allegations. The first is X 2,2,11 (a widow cannot summon a lay person before an ecclesiastical court, unless in an ecclesiastical case, or in the absence of a secular judge), the second D.86 c.3 (who neglects to correct what he can repair, can be blamed for acting). The significance of the latter text for the reasoning remains somewhat unclear. 
cannot possibly support the idea that the Church is competent to protect the poor.

The gloss continues by pointing out that in other cases, i.e. those not related to protection against robbery or infringement on physical integrity, the secular courts are competent. For a further exposition of the demarcation line between ecclesiastical and secular competences, the gloss refers to a gloss of Bernard Parmensis $(\dagger 1266)$ to $\mathrm{X} 2,2,11$ and to the commentary of Innocent IV upon X 1,29,38. Bernard composed the Ordinary Gloss to the Liber Extra, and indeed in the gloss in iustitia ad x 2,2,11 we can read the following: "This makes clear that a case of widows in principle does not come within the jurisdiction of the ecclesiastical judge, although it does so as regards protection (...); cases of widows, pupils and orphans, by contrast, in the first place come within the jurisdiction of the secular court, and in the second place, i.e. as regards their protection, they come within the jurisdiction of the Church (...), although the cases of widows and other personae miserabiles also come within the jurisdiction of the Church, when a remedy is brought because of the injury or violence inflicted unto them"29. In his commentary on $\mathrm{x}$ 1,29,38 Innocent IV deals with the questions: which court is competent in the case of a widow or woman; whether personae miserabiles fall under the competence of ecclesiastical courts; and in what respect they have an exceptional position ${ }^{30}$. Furthermore, for the indemnification of the persons mentioned, the gloss refers to four texts of Canon and Roman law ${ }^{31}$.

This having been said, the gloss comes up with a more specific question: should widows have recourse to ecclesiastical courts? The gloss subsequently follows the distinction, drawn by the French canonist Henri (Hervé) Bohic (Bouhic, Boich, Boyk) (1310-c. 1357), who taught Canon law in Paris. For their 'protection and defence' (protectio et defensio) widows have to resort to ecclesiastical courts. The texts in Gratian's Decree concerning the responsibility of

29 The gloss in iustitia ad x 2,2,11 “(...) Per hoc patet quod causa uiduarum non pertinet principaliter ad ecclesiasticum iudicem, licet pertineat ad ecclesiam quantum ad protectionem (...) immo ad iudicium seculare spectant primo causae viduarum, pupillorum, orphanorum (...) secundario quantum ad defensionem ad ecclesiam spectant (...) licet et causa uiduarum et aliarum miserabilium personarum spectat ad ecclesiam, ubi agitur de iniuria siue de violentia eis illata (...)". This fragment was adopted in the Gloss to Jurisprudentia Frisica 20:9, see Codex Roorda (supra, n. 3), p. 97. Commentaria ad X 1,29,38, n. 1-5. See Innocentius IV, Commentaria (supra, n. 15), fol. 142ra-142vb.

31 These texts are $\mathrm{x} 5,36,7$ (secular authorities who ban a cleric can be sentenced by the ecclesiastical court), C. 8,4,9 and X 1,40,7 (the one robbed may under oath confirm the value of things taken away as estimated by the judge) and C.2 q.1 c.7 (sentencing in contravention of procedural rules is void). 
secular authorities to take the complaints of widows seriously (C.23 q.5 c.26) and the task of sovereigns to come to the aid of widows, easily oppressed by the more powerful (C.23 q.5 c.23), should also be understood in this way. What is meant here, is that these texts should not be adopted as implying that secular courts are automatically competent in cases of widows. As regards 'litigation and defence' (cognitio et defensio), the gloss continues, it depends on the case. If widows want to sue someone because of the injury or violence inflicted on them, they have to turn to the ecclesiastical court and the Church can excommunicate the wrongdoer until he makes satisfaction (C.24 q.3 c.21). If they want to bring other claims, a distinction should be drawn. The ecclesiastical court is competent for possessory remedies, the secular court for petitory remedies. All this can be traced back, almost literally, in the commentary itself of Henri Bohic on the Liber Extra ${ }^{32}$. For the opinion that the Church is competent in case of possessory remedies, Bohic referred to Bernard ${ }^{33}$, Innocent IV and Hostiensis (Henricus de Segusio, $†$ 1271). It would, according to the gloss, also have been endorsed by Petrus de Sampsone ${ }^{34}$. In conformity with such teachings we should interpret what is said in C.23 9.5 C.23 and in the gloss pauperem se dixisset ad $\mathrm{x} 1,29,38$. The former text ascribes the task to protect the disadvantaged to the sovereign; the latter maintains that cases of widows, pupils and orphans come within the jurisdiction of the King or the local lord. Thus again, these texts have to be interpreted restrictively, so that they do not infringe on ecclesiastical jurisdiction, as described by Bohic and others. There is a sound reason for adducing so many authorities to support the idea that the Church is competent in possessory litigation, since this competence, although in $\mathrm{X} 2,2,15$ ascribed to the Church, was claimed by secular authorities, especially by the Kings of France ${ }^{35}$. The gloss concludes with the remark, also to be found in Bohic, that in the absence of a secular judge, jurisdiction devolves to

32 Commentaria ad x 2,2,11, n. 1-2, see Henricus Boich, In quinque libros decretalium commentaria, Venice 1576 , p. 188.

33 The siglum B is used, which probably refers to Bernardus Parmensis, the composer of the Ordinary Gloss.

34 Petrus de Sampsone, who is not mentioned by Bohic, must have taught at Avignon, Orange and possibly also in Béziers. His works are only preserved as manuscripts. Cf. Petrus de Sampsone, Summa decretalium ad x 2,2,11: alioquin hoc est, si esset compertum, quia ad ecclesiasticum iudicem pertineret uel si iudex secularis esset negligens (Basle, University Library, ms. C.I.29, fol. 51va).

35 Infringement on unhampered possession implies an act of violence, which was supposed to make the royal judge competent, since the King is the protector of his subjects against violence. In the fifteenth century, Pope Martin V (1368-1431) acknowledged this secular competence in possessory claims (bulls Romani Pontificis [1413] and Apostolicae Sedis [1429]). 
the Church. This is the well-known jurisdiction ex defectu justitiae, based on a decretal of Innocent III (X 2,2,10).

Isti omnes sunt de iudicio ecclesie quo ad tuicionem et defendendi per sacerdotem xi. q. i. Aliud (C.11 q.1 c.34). Nota. Iniurie et rapine, uidue, orphanis et miserabilibus personis illate, per iudicem ecclesiasticum possunt tueri et defendi, extra de fo. conpe. Ex tenore (x 2,2,11), lxxxvi. d. c. iii. (D.86 c.3); psalmista <dicit> 'Oculi eius in pauperem respiciunt' et alibi 'Orphano tu eris adiutor'. In alys causis tamen principaliter spectant ad forum seculare; de hoc optime in glossa per Bernardum in dicto c. Ex tenore (X 2,2,11), et Innocentius, de offi. delegati c. Significanti. (X 1,29,38). De emendatione istarum personarum dicit, ut extra de iniur. et damp. c. Olim (x 5,36,7), C. unde ui Si quando (C. 8.4.9), ii. q. i. In primis (C.2 q.1 c.7), de his qui ui metus c. fi. (x 1.40.7). Queritur an uidue spectant ad forum ecclesie. Super hoc ponit Henricus Boic istam distinctionem: an ad protectionem et defensionem, tunc dicendum est quod spectat ad forum ecclesiasticum et sic intelligitur c. Amministratores xxiii. q. v. Regum (C.23 q.5 c.26 and c. 23), aut ad cognitionem et defensionem, et tunc aut agitur de iniuria seu uiolentia eis illata, tunc ecclesia potest cognoscere, ut in c. Si quis de potentibus xxiiii q. iii (C.24 q.3 c.21), aut aliis iuribus et hoc dupliciter, aut possessoria, et tunc ecclesia potest cognoscere - ita notant Innocentius et Hostiensis, de fo. conp. in c. Ex tenore (X 2,2,11) aut petitoria, et tunc cognitio principaliter spectat ad iudicium seculare. Ita intelligit Petrus Sampsona et ita potest intelligi c. Regum xxiii. q. v. (C.23 q.5 c.23) et in c. Significantibus de of. delegati in glossa. Et ob defectum iudicis secularis <iurisdictio $>$ bene deuoluitur ad ecclesiam.

The second gloss, starting with the lemma palmerum romerum (palmerem ende Roemfarem), deals with the punishment of those who capture, kill or mutilate pilgrims to Rome. They are excommunicated, probably lata sententia, and can only be absolved by the Pope. Moreover, from C.24 q.3 c.23 it derives that as long as they do not perform satisfaction, they will remain excluded from the Christian community. For the excommunication the gloss refers to the extravagantes which a certain brother Otto had adopted in his additions to the title on excommunication in the Liber Extra (x 5,39). Extravangantes are authoritative decretals, not adopted in the usual collections. The gloss literally quotes the text of this addition: "Similarly, we excommunicate and anathematise all those who, either by themselves or by whatever other persons, have undertaken to capture or despoil from their belongings ecclesiastical or secular persons, seeking refuge to the same. See for the sake of their affairs, etc." 
This text can also literally be found in the bull In Coena Domini, which from 1363 was annually published on Maundy Thursday. Such type of excommunication (lata sententia) may go back to older sources, such as the bull Excommunicamus et anathematazimus (4 April 1303) of Pope Boniface VIII $\left(1235^{-1303}\right)^{36}$.

Palmerum romerum Capientes, occidentes, mutilantes istas romipetas sunt excommunicati et per papam absoluendi, ut in extrauagantibus quas ponit frater Otto in additionibus suis ti. de sententia excommunicationis (x 5,39): 'Item excommunicamus et anathemamus omnes illos qui per se uel per alios quoscunque, personas ecclesiasticas uel seculares ad eandem sedem super suis negocys recurrentes etc., xxiiii. q. iii 'Si quis romipetas et peregrinos (C.24 q.3 c.23), sanctorum oratoria uisitantes, capere aut rebus suis spoliare presumpserint. Donec satisfecerit, communione careat cristiana'.

\subsection{The gloss to the Thirteenth Statute (p. 61)}

The Thirteenth Statute mentions the fine for infringements on a lyoedferd. The latter should mean something such as any sworn renunciation of violence. This Statute may go back to a provision of an older secular truce (treuga terrae). It is provided with a short gloss without lemma, containing two allegations, derived from Canon law. The first enumerates the categories of persons

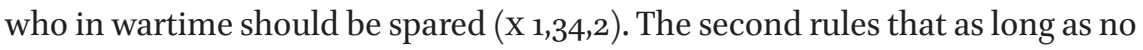
satisfaction is given, the wrongdoer will remain excluded from the Christian community (C.24 q.3 c.23).

De comuni pace, extra de treu. et pace c. ii. (x 1,34,2), xxiiii q. iii. Romipe$\operatorname{tas}($ C.24 q.3 c.23).

\subsection{The glosses to the Fourteenth Statute (p. 61-62)}

The Fourteenth Statute grants the Frisians the right to be restored to their former patrimonial status, when they return after captivity as prisoner of war. They can repossess their assets without legal procedure, even if in the meantime these had been alienated. This right may go back to Carolingian capitularia ${ }^{37}$.

$36 \quad$ Bullarium Romanum Tomus IV, ed. L. Tomassetti e.a., Turin 1859, p. 158-159. However, I did not succeed in finding precursors of the phrasing of the formula of Otto's extravagans.

37 Cf. Monumenta Germaniae Historica, Legum sectio II, Capitularia Regum Francorum I, Hannover 1883, p. 71; Algra, Zeventien keuren (supra, n. 5), p. 326. 
The Statute is provided with two glosses. The first, which lacks a lemma, is entirely based on Roman law texts. It starts by saying that the issue is dealt with in the entire Digest-title 49,15, thereby adopting the indigenous right as the Roman law postliminium, and refers to the third Land Law below ('uide infra in tercio landriucht'). Again, this is a reference to the Twenty-four Land Laws. The third of these, indeed, deals with returning prisoners of war. Furthermore, the gloss refers to Inst. 1,12,5 and to the gloss postliminii to this text. These texts, except the third landriucht, explain the principal Roman rules of law, related to the ius postliminii. The gloss postliminii states that the right is instituted by customs and statutes, thereby referring to D. 49,15,19pr.

The remaining part of the gloss consists of four fragments, literally derived from the Summa Codicis of Azo ad C. 8,50. Azo was a Bolognese glossator, working in the first decades of the thirteenth century, and his Summa on the Codex was an authoritative work, used throughout the Middle Ages, making the Roman law of the Corpus iuris civilis more accessible. The first fragment discusses the etymology of the word postliminium. In the gloss, this fragment is corrupted by a homoioteleuton. The absence of five words from Azo's text makes it difficult, if not impossible, to understand ${ }^{38}$. The second fragment may be the source of the gloss postliminii ad Inst. 1,12,5, just mentioned. It also defines the postliminium-right and states that this right is established by customs between "us and free nations and sovereigns" 39 . The third fragment states that also in case former possessions and rights are acquired by a third party through prescription, there is nevertheless a claim for restitutio in integrum, based on D. $4,6,1$ and C. $8,50,2^{40}$. The fourth fragment explains that the right of postliminium also benefits those who return after being ransomed ${ }^{41}$.

De captiuis et postliminio reuersis etc. per totum (D. 49,15), ubi eis reseruantur omnia iura sua et possessiones restituntur, uide infra in tercio landriucht, et insti. quibus mo. ius $\S \mathrm{Si}$ ab hosti. (Inst. 1,12,5), uerbo postliminium eciam ibi in glossa. Postliminium dicitur a limen et post, quia captus ab hostibus et ultra limina nostri imperii deductus, post intra limina <reducatur, uel reuertatur. Nam limina $>$ sicut in domibus finem quendam faciunt, ita eciam imperii limen ueteres esse uoluerunt; dicitur ergo postliminium, quia post eodem limine reuertebatur, quo amissus erat. Hec Azo C. e. ti. (C. 8,50) in summa. Est autem postliminium ius

38 Summa Codicis ad C. 8,50; Summa Azonis. Summa perutilis excellentissimi iuris monarchae domini Azonis, Lyon 1540, fol. 223rb.

39 Ibid., fol. 223rb.

40 Ibid., fol. 223va.

41 Ibid., fol. 223va. 
amisse rei recipiende ab extraneo et in statum pristinum restituende inter nos et liberos populos regesque moribus constitutum, ff. e. l. Postliminium (D. 49,15,19). Prosit autem ius postliminii in omnibus que michi ante captiuitatem competebant uel mea erant siue sint res mee iura mea amissa prescripcione uel usucapione. Et si amissa sunt subuenitur michi per restitutionem et in integrum data in rem recissoria ff. ex quibus causis ma. l. i. (D. 4.6.1), C. de capti. et postli. reuersis l. Ab hostibus (C. 8,50,2). Non solum prodest ius postliminii reuersis, eciam et redemptis precio, quia redemptio non mutat ius postliminy ff. e. l. Si captiuus $\S$ fi. (D. 49,15,20,2), Azo.

The second gloss, the gloss oen syn ayn gued (oen syn ayn gode), relates to the part of the Statute maintaining that a man who returns from being away can take possession of his own property. It states that this will not be the case, if ownership is lost through short-term prescription of moveable things (usucapio) or long-term prescription of immoveable things, with references to the Codex-titles in book VII, where the various kinds of prescription are described (C. 7,31,1, C. 7,33,12 and C. 7,39,8).

Oen syn ayn gued Nisi obstat usucapio idest de mobilibus bonis uel prescriptio, C. de usuca. transforman. l. unica (C. 7,31,1), C. de prescripionibus et uel xx. annorum l. fi. (C. 7,33,12), C. de prescriptionibus xxx. uel xl. annorum l. pe. (C. $7,39,8)$.

\subsection{The glosses to the Fifteenth Statute (p. 62)}

The Fifteenth Statute establishes the punishment for rape, probably meant here in the broad sense of any attack on decency, including abducting and corrupting women. If a rapist cannot produce the fines, i.e. the amount owed for (preserving) his life and the composition, his kin has to help him out. The latter has to take place in conformity with the doem of the asega and the Land Law.

The Statute is provided with four glosses. The first, the gloss ueduen iefta mageden (weduen jefta mageden), starts with a quotation from a letter of the Church Father Jerome (347-420) which emphasises the evil character of rape ${ }^{42}$. The allegations, which are subsequently brought up, indicate that abduction of honourable women is a scandalous crime and disrespectful towards God (C. 1,3,53 and C. 9,13,1), discuss the various cases of rape (C.36 q.1), and rule that voluntary abduction in view of matrimony is no rape $\left(\mathrm{x}_{5,17}, 6\right)$.

42 Jerome, Letter to the deacon Sabinianus, n. 4; see Hieronymus, Epistularum Pars III [CSEL, LVI/1], ed. I. Hilberg, Vienna 1996, p. 319-320. 
Ueduen iefta mageden Nota ad Sabinianum xi. deflorator uirginum 'infelicissime mortalium, tu speluncam illam, in qua filius dei natus est et ueritas de terra orta est et terra dedit fructum suum de stupro condicturus ingrederis? non times ne de presepe infans uagiat ne puerpera uirgo uideat, ne mater domini contempletur? Angeli clamant, pastores currunt, stella desuper rutilat, magi adorant, Herodes terretur, Iherosolim turbatur et tu cubiculum uirginis uirginem decepturus irrepis et uiolas?' etc. C. de epis. et cleri. l. Raptores (C. 1,3,53), l. 1. C. de rapt. uirgi. (C. 9,13,1), xxxvi. q.i. (C.36 q.1), de raptori. extra c. Cum causam (x 5,17,6).

The second gloss, the gloss haudlesena ielda, refers to the words in the Frisian main text, stating that the rapist has to pay 12 marks for (preserving) his life and remarks that this is in conformity with the rule of Deuteronomy 22, C. 9,13,1 and DG post C.27 q.2 c.10. What is meant here probably, is that capital punishment, which according to the Statute can be bought off, is the proper penalty for 'rape'. Deuteronomy 22.22 reads "If a man be found lying with a woman married to a husband, then they shall both of them die, both the man that lay with the woman, and the woman: so shalt thou put away evil from Israel". C. 9,13,1pr states that abductors of honourable women shall receive the death penalty. DG post C.27 q.2 c.10 refers to the precept of Deuteronomy 22:25 "But if a man find a betrothed damsel in the field, and the man force her, and lie with her: then the man only that lay with her shall die". This having been said, the gloss continues by stating that according to the book of Leviticus the rapist and oppressor have to die, but can purchase their life, just as in the Frisian Statute ${ }^{43}$.

Haudlesena ielda Quia secundum legem deuteronomii xxii, C. de rapto. l. i. (C. 9,13,1) et xxvii. q. ii. Omnem § Item (C.27 q.2 c.10). In Leuitico mori debet raptor et oppressor; et uitam redimere potest L ciclis argenti, ut ibi.

The lemma of the third gloss, hyara ferd ar, cannot be traced back in the main text ${ }^{44}$. The gloss probably refers to the words dis wederjeldis (his own wergeld). It only contains two allegations (C. 9,19,6 and D. 2,1,7), which have in common that both pronounce upon the consequences of not being capable to paying or having no money.

43 Leviticus $27 \cdot 3$.

44 The words "hyara ferd ar" mean "her peace money". They can neither be traced back in the older versions of the Seventeen Statutes, adopted in the manuscripts of the Jus Municipale Frisonum and Codex Unia. 
Hyara ferd ar. C. de sepul. uio. l. ult. (C. 9,19,6), ff. de iurisdicti. omnium judicum Si quis (D. 2,1,7).

The fourth gloss, the gloss so agen syn fryonden, elucidates that the rule of indigenous law, that the rapist's kin has to help him out, clashes with ius commune, since C. 9,47,22 rules that relatives, acquaintances or housemates cannot be charged with the other's crime, as long as they had no part in it. Unlike in many other glosses, Roman law is not applied here to endorse or interpret indigenous law. The gloss is rather of a comparative nature and points out the difference between Roman law and indigenous law.

So agen syn fryonden Contrarium uerum est secundum ius commune. Pena enim tenet suos malefactores, nec ulterius progrediatur metus quam reperiatur delictum. Ibi enim est pena, ubi est noxa. Propinquos ac notos siue familiares submouemus a noxa; hec omnia C. de pe. l. Sancimus (C. 9,47,22).

\subsection{The glosses to the Seventeenth Statute (p. 62-63)}

The Seventeenth Statute grants all Frisians full entitlement to litigation, i.e. to claim and to defend themselves in accordance with the doem of the asega. Moreover, it grants them the procedural right to make statements concerning their own acts and confirm these statements by oath.

This Statute is provided with three glosses. The first one, the gloss by twira taele (bi twira tale) just mentions a principal procedural rule of Romano-canonical procedure, viz. that the judge should sentence according to what parties to the trial adduce and not according to his own conscience. Otherwise he would also be a witness, bringing along own means of proof ${ }^{45}$.

By twira taele Iudex secundum allegata parcium debet iudicare et non secundum conscienciam, quia secundum hoc esset iudex et testis ut et locis suis.

The second gloss, the gloss wyte him self, states that every free Frisian has to account in court for his own acts because no one is allowed to deny these. The argument adduced, C. 3,32,11, implies that the one who seeded another's field,

45 The maxim goes back to the early decretalists and was widely spread among the scholars of Roman and Canon law. See K.W. Nörr, Zur Stellung des Richters im gelehrten Prozeß der Frühzeit: Iudex secundum allegata non secundum conscientiam iudicat [Münchener Universitätsschriften 2], Munich 1967. 
is allowed to declare he acted in good faith. The gloss furthermore explains that in litigation three parties play a role, viz. plaintiff, defendant and judge, which was expressed in the maxim 'iudicium est trinus actus trium personarum $^{\prime 46}$. Sometimes a fourth party is mentioned: the witness. The gloss refers to two allegations, viz. X 5,40,10 and C.4 q.4 c.1. The former gives the etymology of the Latin terms for the parties to the trial: iudex, accusator and reus, while the latter states that in every trial there are four categories of persons: the judges chosen, appropriate plaintiffs, suitable defenders and legitimate witnesses.

Wyte him self Quia nemini licet facta propria ignorare, arg. C. de rei uend. l. Si quis (C. 3,32,11). Tres persone debent esse in iudicio, scilicet actor, reus et iudex, extra de uerbo. sig. c. Forus (x 5,40,10), iiii. q. iiii. c. i. (C.4 q.4 c.1), quandoque quarta persona, scilicet testis.

The third gloss, the gloss uued deen, explains that the testimony, mentioned in the final line of the seventeenth statute, implies judicial notoriety (notorium iuris). In medieval procedural law this meant that denying the testimony required proof. For an argument the gloss refers to $\mathrm{x} 3,2,7$, but the meaning of 'judicial notoriety' is only explained in the gloss notorium to this decretal. Finally, the gloss enumerates the four or five ways in which the court can be convinced of something. In the first place, a fact can be obvious. Secondly, something can be proven by witnesses, as dealt with in the entire title on witnesses of the Liber Extra (x 2,20). In the third place there is the proof by instruments, which can be found in another title of the Liber Extra (x 2,22). In the fourth place, judicial confession can also convince the court, which would derive from $x 2,13,15$ and $x 3,2,10^{47}$. These four ways are mentioned in $x 2,13,15$, while in the gloss dicta testium ad x 2,13,15 an additional fifth way is brought up. This fifth way is violenta presumptio, also termed presumptio iuris. This is a type of statutory presumption, which could be invalidated by proof to the contrary. The gloss refers for further explanation to C.32 q.1 c.2, but the violenta presumptio is only mentioned in the gloss dixit dominus to C.32 q.1 c.2: a man may dismiss his wife when her adultery is proven by violenta presumptio.

Uued deen Hoc est notorium iuris, extra de coha. Clerico. et mulierum c. Vestra $(\mathrm{x} 3,2,7)$. Quatuor modis conuincitur aliquis, scilicet per euidentiam facti, secundo per testes, de testibus per totum $(\mathrm{x} \mathrm{2,20)}$, tercio per

46 This maxim is a locus communis in the scholarly literature on procedural law. See Nörr, Zur Stellung (supra, n. 45), p. 8-11.

$47 \quad \mathrm{x} 3,2,10$ speaks about a sin which can be notorious by confession in court. 
instrumenta, de fide instrumentorum per totum (x 2,22), quarto per confessionem in iudicio factam, extra de resti. spoli. Cum ad sede. (x 2,13,15) et de cohabitione c. fi. (x 3,2,10), si quinto potest addi, scilicet uiolenta presumptio xxxii q.i Dicit Dominus (C.32 q.1 c.2).

The glosses to the Seventeen Statutes: origin, date and edition

\subsection{Origin of the glosses}

The glosses to the Seventeen Statutes are to such an extent related to the Frisian main text, that with all probability they originated in Friesland. At the same time, the glosses show such a familiarity with the sources of learned law, that its authors or compilers must have been jurists, academically trained in Canon law or both Canon and Roman law. At the same time these scholars may have been not so proficient in the study of the Scripture. In the first gloss to the Eleventh Statute, Psalm 10.9 (in the Vulgate Psalm 9.30) was taken entirely out of context and given a signification, which even according to medieval standards seems odd and incorrect.

I speak here about 'jurists' in plural, because it is not unlikely that the glosses were the work of a number of jurists, covering two or more generations. Many Glosses to medieval authoritative texts had more than one version. The original apparatus was often further elaborated through all kinds of alterations and additions until it crystallised out into a so-called Standard Gloss or Glossa Ordinaria. The fact that some of the glosses to the Frisian Land Law were also handed down through other late-medieval manuscripts substantiates this hypothesis and presupposes that the printed version of the glosses in the Frisian Land Law was preceded by a manuscript-tradition. All of this would also include the glosses to the Seventeen Statutes.

At the time the glosses came into existence, there were not yet many universities in the North of Europe. In Friesland there were none. So, we may presume that the jurists who composed and elaborated the glosses were educated elsewhere, e.g. in Italy or France. We know that already in the early thirteenth century there was professional knowledge of Canon law in Friesland. The most famous example is that of the early decretalist Emo van Huizinge ( $† 1237)$, who had studied Canon law at Paris, Orleans and Oxford and became abbot of the Norbertine Abbey of Bloemhof near Wittewierum ${ }^{48}$, but there must have been

48 P. Gerbenzon, Emo van Huizinge, een vroege decretalist. Rede uitgesproken bij de aanvaarding van het ambt van gewoon hoogleraar aan de Rijksuniversiteit te Groningen op 8 juni 1965, Groningen 1965. See for other Frisian clerics who studied law: L.J. van Apeldoorn, Het 
more Frisian canonists with an academic education. Especially where the Gloss mentions works of scholars, which were not as generally quoted during the Middle Ages a more or less direct connection may have existed between the authors of these works and the anonymous Frisian canonists who worked on the glosses. The reference to Petrus de Sampsone could have been added by a jurist who studied in Bologna, where around 1270 the Lectura decretalium of Sampsone was edited ${ }^{49}$. Similarly, we may owe the extensive quotation from the commentary of Henri Bohic to a Frisian canonist, who in the middle of the fourteenth century had studied under this Parisian Professor. However, this remains a conjecture by lack of sources. The Lectura decretalium of Petrus de Sampsone was probably used also outside Bologna, and the works of Bohic could have been accessible in the North of Europe. We know that the Chapter of Saint Martin in Utrecht had a copy of his commentary on the first book of the Decretals, the very part quoted in the Gloss, and it is possible that some Frisian monasteries also had a copy or Frisian canonists consulted the copy in Utrecht $^{50}$. Additionally, the Jurisprudentia Frisica contains references to Petrus de Sampsone ${ }^{51}$. The only canonist mentioned by name in the glosses who may be indigenous, is the unknown frater Otto, probably the same as the frater Otto mentioned in a gloss to Jurisprudentia Frisica 30:26. This Otto must have collected all kinds of additional materials. The gloss on the Seventeen Statutes mentions extravangantes to the title of the Liber Extra on excommunication; the Gloss on the Jurisprudentia Frisica mentions additions to a Summa Confessorum $^{52}$.

Romeinsche recht in Friesland [Mededeelingen der Nederlandsche Akademie van Wetenschappen, Afdeling Letterkunde, Nieuwe Reeks, Deel III, No. 10], Amsterdam 1940, p. 26-28.

49 F. Soetermeer, Petrus de Sampsone, in: Biographisch-Bibliographisch Kirchenlexikon 23, Nordhausen 2004, 1097-1101. The Lectura decretalium never appeared in print. At least sixteen manuscripts have been preserved, not one of these in the Netherlands.

$50 \quad$ See A.J. de Groot and E.C.C. Coppens, Manuscripta canonistica latina. Elenchus codicum necnon diplomatum iuris canonici ante a. 1600 in bibliothecis et archivis neerlandicis, Nijmegen 1989, p. 405 (n. 1466).

$51 \quad$ Codex Roorda (supra, n. 3), p. 236 and 237.

52 Codex Roorda (supra, n. 3), p. 140, Codex Aysma (supra, n. 3), p. 388. In 1292 it was decided that Frisian students in Bologna were assigned to the natio Germanica. In the Acta of the year 1297 a 'dominus Otto de Frisia' is mentioned who bequeathed three solidi. See Acta Nationis Germanicae Universitatis Bononiensis, ed. E. Friedländer and C. Malagola, Berlin 1887 , p. 47 . 


\subsection{Dating the glosses}

If we presume that the Gloss on the Seventeen Statutes gradually developed into the version which was eventually, i.e. by the end of the fifteenth century, put into print, it is probably not older than the Seventeen Statutes themselves, which came into being in the second half of the thirteenth century. Theoretically, the glosses could have been added to the various elements (elaborated Carolingian capitularia) which supplied the materials for the Seventeen Statutes. However, this is not very likely. There are references to papal decretals in many glosses, indicated according to their positioning within the titles of the Liber Extra, while frequently the term 'Extra' is used. This implies that the Liber Extra, promulgated in 1234, had achieved an established position in the teaching of Canon Law. Again, theoretically this could be the result of a later, 13th century elaboration of the glosses, but there are no references to earlier compilations, extravagantes or the compilationes antiquae. Nonetheless, it seems as if the Gloss to the Seventeen Statutes must have taken its more definite shape some time before it was printed as part of the Frisian Land Law. This appeared already from the fact that the lemmata correspond with an older version of the Frisian main text.

The sources and authors quoted suggest that at a certain stage the glosses were not further elaborated or brought up to date. The youngest author quoted is Henri Bohic, who must have died around the year 1357. Whereas the Gloss to the Jurisprudentia Frisica refers abundantly to Bartolus (1313-1357), a most influential civilian, this jurist is not even mentioned once in the glosses to the Seventeen Statutes or other parts of the Frisian Land Law. The same holds true for a number of fifteenth century important canonists. An influential and authoritative canonist such as Nicolaus de Tudeschis or Panormitanus (13861445 ) is not quoted at all ${ }^{53}$. There is one more fact which makes it unlikely that the present edition of the glosses is younger than the end of the fourteenth century. The text quoted as an extravagans which brother Otto had adopted in his additions to title X 5,39, is identical to $\S 12$ of the bull In Coena Domini of 1363. The latter was a notorious and controversial bull, promulgated annually. Thus, it is hard to believe that learned canonists from the fourteenth century would still refer to this text as 'an extravagans of brother Otto'.

\subsection{The edition of the glosses}

Whereas the Gloss to the Seventeen Statutes was in all probability drafted and further developed by academically educated canonists, the editor(s) of the Frisian Land Law did not proceed very meticulously. Even if we ascribe the many 
flaws in the printed text to the negligence of earlier copyists, the editors still did not manage to take out the errors. Whether allegations are corrupt or not is sometimes difficult to judge, since we do not always know why the text, referred to, was in the eyes of the glossator an argument. Sometimes, these texts appear to contain what in our perception are far-fetched or not really convincing arguments. In the above we have noticed that for a number of allegations it is unclear what their meaning can be for the subject under discussion: VI 5,7,11 (gloss alle godes mannen to the Second Statute), D. 43,16,1,15 (gloss onbirawed to the Third Statute) and x 2,26,13 (gloss doer dis edis wille to the Third Statute). One allegation is obviously corrupt. The gloss sikarade mit xii to the Eighth Statute refers for the 'rustic simplicity, that has to be taking into account,' to 'C. de testibus l. ult.. C. 4,20,20, the final provision of the Codex-title de testibus, however, does not say anything about rustic simplicity. The editor, or an earlier copyist, probably interpreted an abbreviated title 'de test.' as 'de testibus', - and in such a way, thus in full and not abbreviated, it can be found in all versions of the incunable - while the abbreviation 'de test.' should have been read as 'de testamentis', Codex-title C. 6,23. After all, the final provision of the Codex-title de testamentis, C. 6,23,31, speaks about illiterates and country-people (rustici). Other flaws consist in the homoioteleuton in the fragment, taken from Azo in gloss postliminii to the Fourteenth Statute, which makes the text in Druk incomprehensible ${ }^{54}$. The gloss uued deen to the Seventeenth Statute refers two times to texts of Canon law, where it should refer to glosses to those texts $^{55}$. Moreover, as stated at the beginning of this paper, the lemmata of the glosses were not adapted to the revised version of the Frisian main text of the Seventeen Statutes. All in all, it seems as if the editors of the incunable themselves had no or only little understanding of the Gloss.

\section{The glosses to the Seventeen Statutes: relation to the main text}

When we analyse the glosses to the Seventeen Statutes, particularly in relation to the Frisian main text, they appear to be of divergent natures. Sometimes they confirm the provisions of indigenous law by adducing texts derived from the sources of Roman and Canon law or they point out mutual differences.

54 Summa Codicis ad C. 8,50: Postliminium dicitur a limen et post, quia captus ab hostibus et ultra limina nostri imperii deductus, post intra limina <reducatur, uel reuertatur. Nam limina $>$ sicut in domibus finem quendam faciunt, ita eciam imperii limen ueteres esse uoluerunt; dicitur ergo postliminium, quia post eodem limine reuertebatur, quo amissus erat.

$\mathrm{X} 3,2,7$ should be the gloss notorium to X 3,2,7; C.32 q.1 c.2 should be the gloss dixit dominus to C.32 q.1 c.2. 
Sometimes they attempt to bring the subject matter of the Statute under the competence of ecclesiastical courts, thereby declaring the law of the decretals in many respects to be applicable. Sometimes they identify notions of indigenous law as a Roman law equivalent or maintain the rule of indigenous law has its origin in Roman law, thereby opening the door for adopting rules of Roman law into indigenous law. Finally, some glosses also refer to rules and notions derived from Romano-canonical procedural law.

\subsection{Comparative glosses}

Some glosses simply endorse the Statute they refer to. They explain what the Statute says by giving examples, derived from Roman and Canon law, or point out that what the Statute instructs can be confirmed by texts of Roman law and Canon law. By referring to learned law, the glosses to the first Statute confirm the entitlement of each Frisian to the unhampered possession of his property. By referring to provisions of Canon law, the glosses uessa menedich and karina schieldich to the Sixth Statute explain the requirements which compurgators must meet for vindicating Church property. The four glosses to the Fifteenth Statute confirm that rape is a reprehensible crime which ought to be punished. The fourth gloss to this Statute, the gloss so agen syn fryonden, also points out the difference between the Statute and the ius commune. According to the ius commune only the wrongdoer has to pay for his crime, not his kin. This remark seems to be of a mere comparative nature, unless the word uerum in 'Contrarium uerum est secundum ius commune' should be read in the sense that the ius commune holds the better opinion.

When the glosses endorse what at least grammatically seems to be stated in the main text, this implies that the scholarly canonist(s) who wrote the glosses, adopted the words of the Statute in their most obvious, grammatical meaning. This we see in the first gloss to the Eighth Statute, which restricts the huisman's right to bring proceedings against his landlord. He should not bring claims (winne) against his landlord too vehemently. The gloss endorses this purport of the words and brings up examples from Roman law. No substantive right may be enforced at the expense of public authorities. The examples mentioned are emphytheusis and monopoly. In the literature, however, this fragment from the Eighth Statute is interpreted in an entirely different way, as mentioned above. It is understood to mean that a huisman should not compete (winne) too vehemently with his landlord. According to this view, the huisman can take an oath of allegiance to his lord, which would prevent him from being forced to take part in a judicial duel ${ }^{56}$. Accordingly, it was argued that the first line of the Statute does not contain any restriction of the huisman's competence to en-

Algra, Zeventien keuren (supra, n. 5), p. 315-316. 
force certain rights against his lord, but a procedural protection against being forced to combat against the landlord. This present-day interpretation is sophisticated and complicated, but the main problem is that it totally ignores the view of the medieval glossator who in any event must have had a better point of departure than later scholars in understanding what the Statute originally was about.

\subsection{Glosses, claiming ecclesiastical competence}

The glosses claim ecclesiastical competence in two areas, whereas the Seventeen Statutes describe the secular law related to the issue, viz. protection of ecclesiastical immunity and protection of the less socially advantaged or personae miserabiles.

The former can be found in the Second Statute. This protection may have had a merely secular origin and nature. The Statute shows no traces whatsoever of ecclesiastical competence. Moreover, it includes the payment of a fine to the frana and a fine for disobeying the King's decree. The glosses, on the other hand, point to ecclesiastical jurisdiction. The gloss alle godes husem states that immunity of the Church is 'derived' (extractum), apart from Codextitle 1,12, from a number of papal decretals ${ }^{57}$. Moreover, the second gloss expands the question of ecclesiastical immunity to the right of Church asylum and acknowledges that in view of $\mathrm{x} 3,49,6$ notorious robbers and plunderers of the fields are excluded from seeking asylum in the Church. Furthermore, it deals with the Canon law consequences of such crimes: the wrongdoers will be excommunicated, and they can be compelled to provide satisfaction.

The protection of personae miserabiles is dealt with in the Eleventh Statute. This provision is believed to have its origin in a capitulare from the year $797^{58}$. Despite this merely secular origin, the first gloss to this Statute points out, that the competence for such matters belongs for the greater part to the Church. This stand leads to an extensive description of the borderline between secular and ecclesiastical competences. The gloss palmerum romerum (palmerem ende Roemfarem) to the same Statute discusses the ecclesiastical punishments for those who capture, kill or mutilate pilgrims to Rome ${ }^{59}$.

57 The entire discussion of the Early modern period whether Church asylum results from the sacred character of the building or is a mere concession by the sovereign is not yet at stake here.

58 Monumenta Germaniae Historica (supra, n. 37), p. 71; cf. Algra, Zeventien keuren (supra, n. 5), p. 326 .

59 Other examples of claiming ecclesiastical competence can be found in the first gloss to

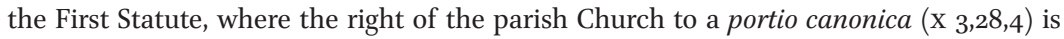


When the Seventeen Statutes were compiled in the second half of the thirteenth century, they were actually already outdated. Many provisions, going back to Carolingian capitularia or old secular truces, had become superfluous or were in fact set aside due to a continuous increase of ecclesiastical competence. In the course of the twelfth and thirteenth centuries the jurisdiction of ecclesiastical courts had expanded considerably. Throughout Europe the Church experienced a juridification, resulting from the centralistic policies of a number of successive Popes. The ecclesiastical competence ratione personarum, dealt with in the glosses to the Eleventh Statute, emerged at the beginning of the twelfth century. Protection of widows in spiritual affairs was introduced by the decretal Ex tenore (X 2,2,11) of Innocent III and possessory protection by ecclesiastical courts was introduced by the decretal Ex parte $(\mathrm{X} 2,2,15)$ of Honorius III $(1150-1227)^{60}$. As a result of these developments, Canon law turned into a major parallel jurisdiction, next to that of secular law, resulting in a situation of legal pluralism. This development must have coincided perfectly well with the emergence of a hierarchically organised Church in Friesland at the expense of the missionary character of the initial Christian community in that region. Already before the first half of the eleventh century, a system of synodical courts was established in Friesland. Its sessions took place annually in the Mother Churches of the former shires Oostergo, Westergo and Zuidergo. Once every four years it was presided by the bishop of Utrecht, the other years by the rural Deans ${ }^{61}$. The fact that no archdeacons played a role in this ecclesiastical litigation indicates that it stems from the period before the formation of archdeaconries in the diocese of Utrecht (midst 11th century $)^{62}$. Thus, if a Statute still reflects the old situation, the glosses may attempt to bring the Statute up to date. Accordingly, what the glosses show here is not a reception of Canon law into indigenous, secular law; they just indicate the increase of ecclesiastical competences at the expense of indigenous, secular law.

mentioned, and in a gloss to the Thirteenth Statute, dealing with ecclesiastical punishment of those who infringe on a Truce.

60 See also R.H. Helmholz, The Spirit of Classical Canon Law, Athens/London 1996, p. 116-144.

61 E.H. Bary / H.D. Meijering, Het Westerlauwers Zeendrecht volgens de inkunabel van het Friese Landrecht, Meidielingen. Stúdzjerjochting Frysk fan de Frije Universiteit yn Amsterdam 1 (1972), p. 9-58.

$62 \quad$ K. van Vliet, In kringen van Kanunniken. Munsters en kapittels in het bisdom Utrecht 6951227, Zutphen 2002, p. 207-208; p. 316-317. 


\subsection{Exegetical glosses, applying Roman law}

The glosses also reveal a distinct influence of Roman law. As throughout Europe, the knowledge of Roman law will have come to Friesland in the wake of Canon law, since for the canonists it was their subsidiary source. All over Europe, Roman law disseminated in the company of the universally valid law of the Church, 'as a lackey on the footboard of canon law's carriage' as it is aptly described in the literature ${ }^{63}$. During their study of Canon law elsewhere in Europe, Frisian canonists could have acquired a considerable knowledge of Roman law, or even obtained a degree in utrumque ius, i.e. both Canon and Roman law. Nonetheless, they appear to be capable of handling the sources of Roman law and understanding the principal scholarly works on Roman law. In some areas of law, the influence of Roman law appears to be more prominent than just providing ancient texts for confirming or illustrating the law of the Statutes. This holds good for the glosses to the Third Statute, dealing with protection of possession and the role of the asega, and the glosses to the Fourteenth Statute, dealing with the return of prisoners of war. The glosses to these two Statutes show a first and cautious use of Roman law, which is mostly achieved in two steps. First, Roman law is used as an interpretational tool: concepts of indigenous law are said to have a Roman origin or are identified as a Roman law equivalent, although the latter is generally far from identical. Secondly, once the indigenous concept is presented in scholarly, Latin disguise, Roman rules, derived from the Corpus iuris, can be used. This mechanism reflects what happened in Western Europe on a larger scale, legitimised by the doctrines of the learned jurists such as Bartolus: the use of ius commune in order to apply the ius proprium ${ }^{64}$.

The Third Statute interprets the entitlement to the peaceful use of one's own land as the Roman possessio. Subsequently, it seems as if possessory protection through interdicts and the possessor's right to defend his possession by answering force by force, both stemming from Roman law, apply to the Third Statute as well. Moreover, as just stated, the Third Statute also deals with the asega. According to the Statute itself the asega is to be sworn into office before the Emperor in Rome. It is questionable what this statement means. According to the secondary literature we may adopt it in the sense that the asega had to be someone who through a previous oath maintained a confidential relationship with the (Frankish) King ${ }^{65}$. The gloss Ende deer aegh nen aesga, however,

63 G. Dolezalek, Canon Law and Roman Law. Some Statistics on Manuscripts in the Vatican Library, in: A Ennio Cortese: Scritti promossi da Domenico Maffei e raccolti I, ed. I. Birocchi e.a., Rome 2001, p. 500-505, at p. 500.

64 Cf. M. Bellomo, The common legal past of Europe 1000-180o, Washington 1995, p. 184-195.

65 Algra, Zeventien keuren (supra, n. 5), p. 44-47. 
takes the statement literally, which evokes many questions. The gloss states that this precept is 'adopted' (hoc sumptum est) from C. 3,1,14. Does the Gloss say here that the Statute refers to a continuous tradition going back to Roman Antiquity? This could be the intention of the Gloss, but it is not very likely that such continuity indeed existed. The Lex Frisionum (c. 790) does not embody any text which may endorse such a thing. The Codex Justinianus itself was only available from the beginning of the twelfth century ${ }^{66}$. Could it be that the Gloss tried to assimilate the asega to secular judges, appointed by the Emperor of the Holy Roman Empire? This would substantiate the idea that in Friesland the secular judge should apply the law of the German Empire, i.e. Roman law, as counterpart of the ecclesiastical judge, applying Canon law, thus pointing to an early reception of Roman law. These questions are difficult to answer, but it is clear that once the asega is labelled as the Roman iudex, the gloss ende als di aesga nympt onriucht declares all kinds of Roman provisions to be relevant for the asega: D. 5,1,15, C. 7,49,1, C. 7,64,7, C. 9,27,1, C. 9,27,4, etc. Accordingly, Roman law endorses some of the indigenous precepts, e.g. that magistrates should not be bribed, but at the same time it seems to be determinative for the interpretation of such a precept.

Similarly, the glosses to the Fourteenth Statute adopt the right of those who return after having been captured by the enemy as the Roman law ius postliminii. With all probability, however, the Statute had its origin again in Carolingian capitularia and not in Roman law ${ }^{67}$. Nevertheless, labelling an indigenous right with a Latin label, justifies referring to the Summa Codicis of Azo and additional rulings of Roman law, discussed there, such as those dealing with restitutio in integrum (D. 4.6.1 and C. 8,50,2) and returning after being ransomed (D. 49,15,20,2).

\subsection{Exegetical glosses: indigenous and learned procedural law}

The glosses adopt the old asega, mentioned in the Third Statute, as a judge in the Roman sense and this may have been a deliberate attempt to adapt the old Statute to an altered situation. Indigenous procedural law had changed between the time the single Statutes had come into being and the time the glosses were written. Moreover, Romano-canonical procedure had emerged,

66 If there was indeed a source from Antiquity to rely on, it is more likely that it was De offciis of Cicero (106-43 BC), which work was known and accessible throughout the Middle Ages and describes the oath, taken by the judge in Rome, although in Cicero's days there was no Emperor. De officiis 3.10.43-44, see Cicero, De officiis, London etc. 1928, p. 310 and 312.

67 Monumenta Germaniae Historica, (supra, n. 37), p. 65; cf. Algra, Zeventien keuren (supra, n. 5), p. 336 . 
and this way of litigation soon became determinative for any kind of scholarly writing on legal procedure. As regards Frisian law, we know that around the middle of the thirteenth century the outcome of litigation was no longer determined by an asega, but by county judges (grietmannen), elected by freeholders (eigenerfden). Either together with other freeholders or by himself, such a county judge would determine the outcome of the proceedings and pass judgment. Accordingly, when putting the old asega on a par with the Roman iudex, the author(s) of the glosses could have had in mind the judicial magistrates of their own days.

Similarly, the procedural law, dealt with in the Seventeenth Statute, must have been outdated at the time the glosses were written. It may well be that this Statute had its origin in Carolingian times, since it explicitly claims to contain a privilege granted by Charlemagne to the Frisians. Moreover, the ancient asega and his doem are mentioned. On the one hand, the Seventeenth Statute does record the basic principles of the old indigenous, procedural law. At the other, this is restricted to those provisions which still have a practical significance. The glosses either support these provisions by adducing maxims from the Romano-canonical procedure or describe certain indigenous notions in technical terms, derived from the same. The basic principles appear to be (i) the contradictory procedure, characterised by indictment and defence, (ii) the full status of the parties in litigation, who themselves can give testimony concerning their own acts, and (iii) the tenability of such statements. It is hard to conclude, that elements of Romano-canonical procedural law, as they can be traced back in the works of the early canonists, more specifically in the ordines iudiciarii, had already become operative in secular litigation; nevertheless we must acknowledge that the author(s) of the glosses already linked these elements to the procedural practice of their days.

\section{5}

\section{Conclusions}

As regards the date of the glosses to the Seventeen Statutes of the Frisian Land Law, it is only possible to come to a cautious hypothesis. By the time the Statutes were compiled i.e. in the second half of the thirteenth century, they were already outdated. Many a Statute stemmed from Carolingian capitularia, i.e. it had its origin in the eighth or ninth century AD. From that time onwards, many things had changed. The Church in Friesland became more firmly established and Canon law had gained a stronger position as a parallel jurisdiction with its own competences. In all probability, it was, in view of legal practice, highly necessary to rewrite the text of the Seventeen Statutes, but an authoritative 
Gloss could have had the same effect. If this was indeed the case, it is likely that the glosses came into existence not long after the Seventeen Statutes were compiled. Especially the references to Canon law point out that the glosses were aimed at bringing the Seventeen Statutes up to date. They had to point out to the reader the altered legal reality, characterised by the complexities of legal pluralism.

If we can indeed date the glosses cautiously between the middle of the thirteenth and the end of the fourteenth century, as a matter of fact new questions arise. The glosses show that Roman law was used to interpret the indigenous provisions of the Statutes. However, this would imply that Roman law was prominently present in Friesland much earlier than previously assumed in secondary literature. The latter regards the 'turning point' of 1504 , i.e. the introduction of a new Saxon ordinance, at which occasion the Frisians opted for imperial (Roman) and not for Saxon law, as the decisive moment for reception of Roman law in Friesland. In 1940 it was L.J. van Apeldoorn (1886-1979) who defended the view that already in the twelfth century Frisians clerics regarded Roman law having binding force in Friesland ${ }^{68}$. The glosses to the Seventeen Statutes of the Frisian Land Law confirm this view, viz. a firm presence of Canon and also Roman law, long before $1504^{69}$.

What can we say about the date of the Frisian Land Law as a compilation? If the glosses to the Seventeen Statutes were indeed not further elaborated after the end of the fourteenth century, this would imply that already before that time there were connections between the various law texts which constituted the 'canon' of classical texts. As we saw, the glosses contain references to several such other texts, as What is law?, the Twenty-four Land Laws and the Synodical law. It may even be, that the classical 'canon' was already in existence at that time. Investigations into the glosses to other parts of the Frisian Land Law, may confirm this. A decline around 1400 of elaborating and glossing the Frisian Land Law, would coincide perfectly with the emergence, not long after 1400, of a younger type of legal literature i.e. that of the Excerpta legum. In the new

68 Apeldoorn, Het Romeinsche recht (supra, n. 48), passim.

69 This is more or less confirmed by some Frisian medieval charters, containing references to Roman law, also implying that before 1500 there were indeed connections between learned Roman law and day to day legal practice in Friesland. See P. Sipma, Oudfriesche oorkonden II [Oudfriese taal- en rechtsbronnen, 2], The Hague 1933, n. 31 (p. 40) and n. 43 (p. 59); O. Vries, Oudfriese Oorkonden IV [Oudfriese taal- en rechtsbronnen, 14], The Hague 1977, p.123-129 (n. 112) and P. Gerbenzon, Excerpta legum. Onderzoekingen betreffende enkele Friese rechtsboeken uit de vijftiende eeuw, Groningen 1956, p. 451-457. Moreover, there are more examples of an early application of Roman law in Northern Europe, such as in the municipal law of Jerichow (c. 1350). Cf. H. Krause, Kaiserrecht und Rezeption, Heidelberg 1952, p. 84. 
compilations, belonging to this category, the classical texts as such were no longer preserved, but single legal provisions were compiled, thereby incorporating many rulings of Canon and Roman law $^{70}$. A good example is the Jurisprudentia Frisica, mentioned various times above. If indeed the new tradition put aside the classical texts, it is debatable whether the Frisian Land Law, which by the end of the fifteenth century must have been insufficiently adapted to the altered circumstances and highly antiquated, was edited in print, thereby entailing considerable expense. This enticing question, however, lies beyond the scope of the present contribution.

$70 \quad$ Gerbenzon, Excerpta legum (supra, n. 68), p. 391. 